\title{
Postcolonialism and translation: the dialectic between theory and practice
}

\author{
Paul F. Bandia \\ Concordia University, Montreal
}

\begin{abstract}
Postcolonial intercultural writing has been likened to translation both in terms of the writing practice and the nature of the postcolonial text, which often involves multiple linguistic and cultural systems. To highlight the significance of this view of translation as a metaphor for postcolonial writing and its impact on current translation theory, this paper attempts to lay the groundwork for defining the linguistic and cultural status of postcolonial discourse and to establish parallels between the translation process and some strategies for crafting the postcolonial text. The ontological relation between translation theory and practice is discussed in the light of postcolonial translation practices which have broadened the scope of research in translation studies to include issues of ideology, identity, power relations, and other ethnographic and sociologically based modes of investigation.
\end{abstract}

\section{Introduction}

This paper seeks to define and describe the linguistic and cultural status of the postcolonial text, establish the relation between postcolonial writing and translation, and discuss the dialectic between translation theory and practice in the light of contributions from postcolonial translation studies. The empirical data is drawn from African European-language literature, which is characterized by hybrid formations that blend indigenous and Western metropolitan traditions. As a postcolonial text, Euro-African writing is characterized by a form of linguistic and cultural hybridity that is achieved, for the most part, through specific translation practices. It has been said that postcolonial texts are themselves translations often based on multiple linguistic and cultural systems. This has led to the characterization of postcolonial translations as rewriting, thereby highlighting the specificity of this kind of translation practice. It therefore becomes necessary to explore the ideological and socio-cognitive factors that determine the strategies involved in the writing and translating of such postcolonial literatures.

Rather than dwelling on notions of equivalence and fluency in translation, postcolonial translation studies is mainly concerned with investigating the impact of translation on a colonized source culture, and the consequences for a homogenizing or colonizing language culture. The analysis carried out here is based on a text-linguistics approach, making use of concepts and tools from the sub-fields of discourse analysis and pragmatics. This approach makes it possible to transcend the limitations of a purely lin- 
guistic approach to translation studies, and allows us to have a broader view of language in use as well as to account for linguistic variation within the postcolonial text. The approach is better suited to studying peripheral or marginalized language cultures and their translations, such as Euro-African literatures.

\section{Linguistic and cultural status of the postcolonial text}

In order to ascertain the impact of postcolonial translation studies on general translation theory and practice, it is important to define and characterize the postcolonial text. How does it differ from mainstream Western metropolitan varieties? What are the discourse or writing strategies that account for its difference or specificity? What is the relationship between postcolonial Europhone fiction and the indigenous oral narrative? These are some of the questions that are fundamental to establishing the status of postcolonial discourse.

\subsection{Theoretical framework}

From a methodological perspective, our attempt at characterizing the EuroAfrican text draws heavily on approaches that fall within the parameters of studies in cross-cultural pragmatics, or intercultural communication. Our pragmalinguistic approach (Blum-Kulka 1985) is based on the assumption that speech communities tend to develop culturally distinct communication strategies, which are characterized by culture-specific features of discourse. We contend that such culture-specific features are either consciously or unconsciously transposed from the native languages and cultures of African writers into their European-language works. In order to isolate these culturespecific features our analysis goes beyond the level of sentence grammar (sentence-bound and so context-free) to deal with text-grammar, including several extra-linguistic factors.

According to Hymes's theory of communicative competence (1972: 269), the members of a given linguistic community are aware of the rules of language, the rules of speaking and all aspects of social behaviour that affect speech in that community. This theory is relevant to the study of postcolonial discourse in that it suggests that whenever two linguistic communities come together the two languages in question provide the speakers with two systems of communicative competence. The members of each linguistic community are likely to transfer their native competence onto the second language adopted by the community. In such a situation the measure of each member's bilingualism is based upon the degree to which his/her competencies in both languages merge. In the African postcolonial context, the African writer is often a bilingual and bicultural subject who has a good 
command of his/her native African language and his/her European language of writing. The apparent non-nativeness of the African writer's Europeanlanguage text can only be gauged in terms of the differences between his/her variety and the presumed ideal communicative competence, namely the European variety of the language as used by those for whom it is a mother tongue. Postcolonial European-language writing is indeed the result of a form of radical bilingualism (Mehrez 1992), evoking two alien, or remote, language cultures simultaneously. This has led to the assumption that African Europhone literatures are themselves translations, an assumption which highlights the role of translation in shaping and defining African varieties of European languages (e.g. English and French). The African writer's translational position (position traductive (Berman 1995)), which is informed largely by his/her bilingual and bicultural background, is determined by the degree to which the writer-translator chooses either to respect the translational norms of the receiving European language culture or to ensure the formal as well as ideological representation of the colonized source language culture.

\subsubsection{Ethnography of speaking: traces of African orature}

In the postcolonial context, when African and European discourses merge, the difference in perception of socio-cultural interactional norms and values and social situations that exists between the traditional African society and its European counterpart makes for a peculiar African discourse-type in European languages. Although it is generally agreed that aspects of folklore and other residual techniques of oral tradition abound in much modern fiction written in Africa (Anozie 1981: 355), the methods used to account for this phenomenon have been relatively superficial and limited to the obvious cases of direct transfer (transposition) of whole segments of texts of some African narrative genres onto European languages (Obiechina 1975; Chinweizu and Madubuike 1980). Apart from Zabus's The African Palimpsest (1991), which deals specifically with the indigenization of European languages in Africa through a process of relexification, hardly any significant attempt has been made to account fully for the inherent intertextuality of African European language writing from a translation standpoint. Like most postcolonial literatures, Euro-African literature often draws heavily on related oral traditions through a process whereby creative writing takes the form of rewriting as translating. Generally, there has been a tendency to seek to assert an African identity in Euro-African literature through a process of writing as translating based on a selective exploitation of various aspects of African oral narratives. As translations, these oral narrative features occur in postcolonial texts in varying degrees of subtlety ranging from bold translations to mere traces that can only suggest the existence of an oral narrative subtext. 


\subsubsection{Discourse and social relations}

Speech act studies are often based on the assumption that "the minimal units of human communication are not linguistic expressions, but rather the performance of certain kinds of acts such as making statements, asking questions, giving directions, apologizing, thanking, etc." (Blum-Kulka et al. 1989: 55). While some theorists claim that speech acts operate by universal pragmatic principles (Austin 1962; Searle 1969, 1975), others believe that speech acts vary in conceptualization and verbalization across cultures and languages (Green 1975; Wierzbicka 1985). It has also been said that the modes of performance of speech acts carry heavy social implications (ErvinTripp 1976) and seem to be governed by universal principles of cooperation and politeness (Brown \& Levinson 1978; Leech 1983). Yet it has also been observed that speech communities have different preferences for modes of speech act behaviour. Culturally coloured interactional styles create culturally determined expectations and interpretative strategies, and can lead to breakdowns in intercultural and inter-ethnic communication (Gumperz 1978).

Some markers of social relations and some social-situational factors thus affect verbal interaction among Africans in a traditional setting, and African writers have sought to retain these culture-specific characteristics of traditional African discourse in European-language writing. The problems such cultural differences pose for cross-cultural communication are many, as clashes between different interactional styles can often lead to intercultural miscommunication. Translation serves to bridge this intercultural gap, as can be shown by highlighting the characteristics of Euro-African hybrid discourse. Postcolonial intercultural writing attempts to rise above these cultural differences by seeking textual middles (Lecercle 1990) that is, meeting points where differences are negotiated and reconciled into new hybrid formations that are indeed evocative of both alien cultural systems. These hybrid formations are truly representative of postcolonial text, which is based on a multi-layering of different linguistic and cultural discourses.

\subsection{Discourse-types and textual hybridity}

For purposes of illustration, the following are two main discourse-types prevalent in Euro-African literature. The examples show clearly that postcolonial texts are hybrid in nature, and highlight some of the strategies at work in the writing-as-translating process involved in intercultural writing.

\subsubsection{Indirectness in discourse}

Discoursal indirectness, as practised in traditional Africa, is often emulated by Euro-African writers resulting in a peculiar discourse-type. By indirect- 
ness we mean the strategy of making a point or statement in a roundabout manner, through circumvention, calculated delays, pausing, and so on. By using indirect language the traditional African speaker can display great skill in oratory, often through the display of knowledge or wisdom, and his/her ability to use such devices or discourse strategies as inclusion (or group identity), shared meaning, textual coherence, proverbs, rhetorical questions, etc. (see Enahoro 1966; Obiechina 1975; Kaplan 1980; Chishimba 1984). Sometimes Westerners with a universalistic mind-set find the devices or strategies of indirectness used by Africans in a conversational situation to be confusing and even a waste of time. This misunderstanding often leads to miscommunication and charges from the West of the apparent irrationality and superficiality of African discourse. According to Kaplan, there are at least four ways of encoding information logically and these are correlated with socio-cultural origin. They are linear logical sequencing, parallelistic logical sequencing, zig-zag sequencing, and circular sequencing (1980: 410). Ways of producing discourse may thus differ from one socio-cultural group to another.

\subsubsection{Discoursal indirectness and hybridity}

It is not surprising that some African peoples who do not traditionally use the written word for formalized transactions or artistic expression should have developed the oral skill of public speaking to perform these functions. An accomplished speaker in a traditional African context is someone blessed with many qualities, amongst which is the quality of possessing profound knowledge of, and ability to transmit, notions and ideas which generally portray the speaker as being wise and knowledgeable. Wisdom is certainly also highly valued in many cultures, and a knowledgeable person is generally one who shows special skills in recalling events and putting them in a wider context as befits the expectations of his/her contemporaries. Knowledgeability also includes the ability to manipulate language: an ability which is cultivated with time, or inherited, as is the case with most traditional praise-singers in Africa. This skill is closely associated with oratorical ability where the speaker deliberately resorts to the strategy of discoursal indirectness. Today, such knowledge is not exclusive to the praise-singer neither does it manifest itself only in set forms such as elegies and panegyrics. Knowledgeability, or wisdom, occurs in everyday conversations, either in a situation where an older person advises, cautions or educates a younger person, or when a king is being addressed by his/her subjects in a circular language, full of symbolism and imagery.

African writers often attempt to reproduce these rhetorical skills in their European language texts particularly in direct speech events such as in dialogue or in monologue. As can be seen in the following example, the result is often a form of bicultural, and sometimes bilingual, hybrid text characteristic of postcolonial writing. 
(a) I salute you all... When an adult is in the house the she-goat is not left to suffer the pains of parturition on its tether. That is what our ancestors have said. But what have we seen here today? We have seen people speak because they are afraid to be called cowards. Others have spoken the way they spoke because they are hungry for war. Let us leave all that aside. If in truth the farmland is ours, Ulu will fight on our side. But if it is not we shall know soon enough. I would not have spoken again today if I had not seen adults in the house neglecting their duty. Ogbuefi Egonwanne, as one of the three oldest men in Umuaro should have reminded us that our fathers did not fight a war of blame. But instead of that he wants to teach our emissary how to carry fire and water in the same mouth. Have we not heard that a boy sent by his father to steal does not go stealthily but breaks the door with his feet? Why does Egonwanne trouble himself about small things when big ones are overlooked? We want war. How Akukalia speaks to his mother's people is a small thing. He can spit into their face if he likes. When we hear a house has fallen do we ask if the ceiling fell with it? I salute you all. (Achebe, Arrow of God: 162)

(b) is our paraphrase of the above speech for the purpose of illustration:

Our ancestors believed that it is the responsibility of the adult to share his wisdom with the young so as to prevent the young from following the wrong course in life. Instead, today what we see here is adults neglecting their duties, because they are afraid to be called cowards. Others have said things that only betray their resolve to go to war. But all that is beside the point. The fact is, if the farmland is really ours we can count on our god Ulu to be on our side. But remember Ulu shall not take part in an unjust war. I would not have spoken again today if I had not seen adults in the house neglecting their duty. Ogbuefi Egonwanne, as one of the three oldest men in Umuaro, should have reminded us that our fathers never fought an unjust war; but rather he encourages the young emissaries to go and deliver a message of war and yet he expects them to do so peacefully. If you send an emissary to declare war on your enemy it doesn't really matter how he does it. Egonwanne therefore does not seem to have his priorities straight. The fact is we want war and it does not really matter how we declare it. Thank you.

Passages (a) and (b) are obviously different from a rhetorical point of view. Passage (b), which is our paraphrase of passage (a), is far from what Achebe would have his village elders say. As Achebe puts it, passage (b) is not "in character" with the "ways of speaking" (Hymes 1972: 279) of the Ibgo people. It may be closer to the standard metropolitan variety of English; however, it does not have the same ethnolinguistic, or culture-specific, characteristic of Igbo speech as illustrated in (a). Thus, (b) is a de-Africanized version of (a) for the following reasons:

- In passage (a) the speaker begins with a proverb and concludes with another proverb, which gives the text a distinct local flavour and also a dose of authority since proverbs are indicative of wisdom and knowledgeability. 
- In passage (b) the proverbs, as well as the rhetorical questions, have been translated into straightforward declarative and assertive statements, with the result that the tone of the text is flat and the local colour is lost. The speaker's comments appear blunt and direct.

Although the speaker is highly critical of another village elder for his irresponsible behaviour, the message in (a) is laced with wisdom and couched in very subtle and carefully crafted language, designed to make a point without engaging in any obvious personal and direct attack. The latter is made possible through the rhetorical practice of discoursal indirectness.

From a discourse analysis standpoint, the target reader (or listener) is expected to grasp the nuances of the speech through a process of interpretation based on grasping the inference, implication and implicature (Grice 1975) embedded in the proverbs and rhetorical questions. Indeed, the culture-specific strategies found in traditional African discourse give African literature in European languages a peculiar flavour. A main characteristic of traditional African discourse is the fact that logical linearity is not a necessary strategy of discourse production. Sometimes the reader can only make sense of a text by putting together an underlying logicality linking the statements, based on non-textual clues and some knowledge of African discourse production strategies.

As indicated earlier, traditional African discourse tends to value discoursal indirectness, and in this context, textual coherence is usually not based on propositional or illocutionary unity as is often the case in Western discourse analysis. Regarding traditional African discourse, textual coherence can refer to such logical relations as connectedness, verbal marking of sentence unity, topic-comment relation, etc. Therefore, studying the textual coherence of traditional African discourse would imply investigating items such as linearity, circularity, parallelism, implication, implicature, assertion, inference, etc.

\subsubsection{Linguistic experimentation and hybridity}

Euro-African literature can also be characterized in terms of the basic linguistic influences of traditional African discourse on European-language writing. These influences can be observed at the lexical, syntactic and sentential levels, and they account for the lexico-grammatical processes involved in the Africanization of colonial languages. The indigenized (Zabus 1991) texts are hybrid in nature in that they are the result of a contextualization (Kachru 1983) process whereby certain context-specific features are assigned to a second language in order to make it a part of the meaning and behaviour potential of the postcolonial subject. The assigning can occur through linguistic processes such as transfer, interference, lexical innovation, collocational shifts or semantic shifts. 
The following is an example of a hybrid Euro-African text produced through a form of radical bilingualism:

\begin{abstract}
You asked me why I am giving you my hands in this happening-thing, when you have become the enemy of everything in the town? Well, I am giving you my hands and my inside and even my shadow to let them see in their insides that if even the people do not know, we, you and I, know and have prepared our bodies to stand in front of them and tell them so. They now feel that I really am a witch, so I put fear into their insides. That sweetened my inside because I had wanted to remain a witch in their eyes so that I could do something against them. Then you returned, and when I started to hear the happening-things in your name, my hopes rose to the eye of the sky. And then yesterday you came running, being pursued by the people. So I called you in. These are my answering words to your questioning words. (Okara, The Voice: 56$)$
\end{abstract}

This text, though an extreme case of transliteration, shows how the English language has been othered into a hybrid linguistic form with the underlying presence of an African idiom. The author, Gabriel Okara, claims to have translated oral narrative forms literally from his native Ijaw language into English, in an attempt to stay as close as possible to the intended meaning. This verbatim translation produces a curious mix of English words in a syntax that is alien to the English language but reflective of the lexico-grammatical structure of the Ijaw language. Expressions such as "my inside", "my shadow", "this happening-thing", "my answering words to your questioning words", "the eye of the sky" - examples of collocational and semantic shifts - are a unique expression of African idiom in English. They are indeed hybrid in nature as they simultaneously evoke two distinct linguistic systems (i.e. African and European). As a creative writing technique, this type of linguistic experimentation can only lead to a dead end as it seems somewhat unrealistic to attempt to create a fully-fledged language based on a literal translation from one distant, alien or disparate language to another.

There are other strategies of representation through innovative formalisms used by African writers to highlight the cultural specificity of their work. For instance, some authors use indigenous language words and expressions, or pidgins and creoles, and either translate or explain them within the European language text. This is understood as a form of ideological representation of the work's Africanness through a conscious disruption of the fluency of the European language text and a deliberate violation of the linguistic and aesthetic norms of the receptor colonial language.

Only with a clear understanding of these discourse strategies can one begin to grasp the full meaning potential of a postcolonial Euro-African text, even before embarking on any form of cross-cultural (and cross-linguistic) transfer.

The two examples (discoursal indirectness and linguistic experimentation) discussed so far are an attempt to characterize African postcolonial dis- 
course, and to establish the relationship between strategies for creating this hybrid discourse and the translation process. Tymoczko (1999) has argued convincingly that postcolonial intercultural writing is similar in many ways to interlingual translation. Using interlingual literary translation as an analogue for postcolonial writing, she explores the concept of translation as metaphor for postcolonial writing. This concept, which views postcolonial writing as a form of translation, understands the activity of translation as the carrying across, the transportation and relocation of cultures from a marginalized or peripheral position to a more central and more powerful one. After discussing some of the similarities and differences between postcolonial writing and interlingual translation, Tymoczko arrives at the following conclusion:

Thus, although there are differences between literary translation and postcolonial writing, such differences are more significant prima facie than they are upon close consideration. The two types of textual production converge in many respects; as the metaphor of translation suggests, the transmission of elements from one culture to another across a cultural and/or linguistic gap is a central concern of both these types of intercultural writing and similar constraints on the process of relocation affect both types of texts.

(1999: 22-23)

There are indeed parallels between a translator's choices in transmitting a source text and the choices made by a minority-culture writer in representing his/her indigenous culture in an alien dominant language.

\section{Postcoloniality and translation studies}

Postcolonial approaches to translation studies have had a significant impact on the assessment of the relationship, or the dialectic, between theory and practice. For one thing, mainstream notions of equivalence and fluency have been put to the test, and traditional models often based on binary oppositions such as source/target, primary/secondary, faithful/unfaithful have been shown to be rather limited. Questions have been raised regarding the concept of the original and the rapport between the original and the translated text. For instance, the view of translation as a metaphor for postcolonial intercultural writing raises the question of the original from which such texts are crafted. The definition of such an original is necessarily different from the classic understanding of the term, since the relationship is partial and not whole as only traces of the original can be found in the written text. Also, far from being a concrete or palpable entity, the original is often abstract or elusive, embedded in the oral tradition of the writer-translator's native culture. Furthermore, once it is written down the 'translated' postcolonial text appears to be no longer bound by the exigencies of the original as it seeks to project its autonomy assuming different functions and a life of its own. 


\subsection{Universal pragmatics and translation}

Some basic concepts of universal pragmatics and intercultural communication can help elucidate the impact that postcolonial writing as translation has had on the discourse of translation theory and practice. The ethical stance of language philosophers such as Habermas and Gadamer regarding some fundamental universal principles of communication can shed light on the concept of intercultural writing as translation, its significance for translation theory and practice, as well as on the ideological underpinnings of such a writing practice.

In Habermas's $(1979,1984)$ discussion of universal pragmatics and communicative action one point stands out which seems quite significant for the discussion of the accessibility of postcolonial hybrid texts to non-African readers. He argues forcefully that success or failure of communication is not merely a question of comprehensibility (in the linguistic sense) but of acceptability. Basically, if the comprehensibility of one's utterances is questioned, communication can continue only if the misunderstanding is cleared up (through explication, elucidation, paraphrase, translation, semantic stipulations, etc.). The main thrust of Habermas's theory is the preeminence of universal conditions of possible understanding (1979: 24). Questions have been raised by some critics who generally perceive postcolonial intercultural writing as a deliberate practice of obscure and opaque writing. This mainstream homogenizing view is less receptive to the kind of radical bilingualism (or radical translation, to borrow Quine's (1960) words) practised by African writers, which appears to do violence to the norms of the Western variety of European languages. Habermas's theory (as well as Gadamer's (1976) hermeneutic reflections) emphasizes the unity of reason in the plurality of natural languages. As stated by Habermas, "We are never locked within a single grammar. Rather, the first grammar that we learn to master already puts us in a position to step out of it and to interpret what is foreign, to make comprehensible what is incomprehensible, to assimilate in our words what at first escapes them" (1984: 255).

In Gadamer's view, understanding and interpretation are closely linked. Difficulties in understanding and the need for interpretation constantly arise even in one's own language. Regarding translation, he observes that although understanding cannot be achieved that is free of the interpreter's own life-world, only by further penetrating the material of an alien language with an openness for cultural differences can the interpreter's preconceptions derived from his or her own cultural background show themselves to be arbitrary. All interpretive understanding is necessarily bound to preconceptions and prejudgments. However, it is by being open to other cultures that interpreters become aware of their prejudices in the course of their interpretive activity. Gadamer states the following:

The interpreter, like the translator, must capture the sense of his material in and through articulating it in a symbolic framework different from that in 
which it was originally constituted as meaningful. And as the translator must find a common language that preserves the rights of his mother tongue and at the same time respects the foreignness of his text, so too must the interpreter conceptualize his material in such a way that while its foreignness is preserved, it is nevertheless brought into intelligible relation with his own lifeworld. (qtd. in McCarthy 1978: 173)

Gadamer believes that language and tradition are inseparable, and the interpreter is only a concrete historical subject of his/her own tradition whose understanding is shaped by the values of that tradition. Yet, as Gadamer points out, any conception of hermeneutic understanding should necessarily transcend such limitations.

In Habermas's view, the interpreter willing to use his/her power of scientific reflection is likely to overcome the influence of dogmatism of life practice. With this line of argument Habermas relates hermeneutic interpretation to the critique of ideology. He says:

Language is also a medium of domination and social power. It serves to legitimate relations of organized force. In so far as the legitimations do not articulate the relations of force that they make possible, in so far as these relations are merely expressed in the legitimations, language is also ideology [...]. (1984: 287)

Habermas's critique of ideology can shed some light on the language practice of postcolonial writers in Africa. Though 'victims' of their own concrete hermeneutic situation and tradition, African writers seek to deny language its role as a medium of domination and social power, by subverting the colonial language. The European language is othered in an attempt to retain the foreignness of the African culture in a process of translation as representation. Contextualizing, or indigenizing, colonial languages is a well-known strategy in the quest for identity vis-à-vis a universalizing (or homogenizing) metropolitan culture. The culturo-linguistic constitution of this hybrid writing is also a reflection of the historical reality of the postcolonial experience. This hybrid discourse - the result of a practice of radical bilingualism or transculturality, evoking two alien, or remote, language cultures simultaneously - enhances our understanding of the role of translation as representation grounded in ideology, and the role of translation as subversion in violating the norms of the receiving colonial European languages.

African European-language writers have elected to "preserve the original function of the source text in its culture" (Snell-Hornby 1988: 44) thus preserving the "situation of the source text" (ibid.), a judicious choice viewed from the vantage position of a postcolonial bilingual and bicultural subject. Postcolonial writing as translation is, to a degree, about conveying one's sociocultural life-world through the medium of an alien language weighed down by its historical and ideological load as a language of colony and postcolony. 


\title{
3. Conclusion
}

According to Jakobson: "All cognitive experience and its classification is conveyable in any existing language. Whenever there is deficiency, terminology may be qualified and amplified by loanwords, or loan translations, neologisms or semantic shifts, and finally by circumlocutions" (1959: 234). Indeed, representations of Africanness in European-language writing have been made possible through such translingual and transcultural processes as loan translations, semantic shifts, shifts in norms and cultural circumlocutions. Regarding the apparent limitations of the hybrid postcolonial text, we can only echo Gadamer's and Habermas's view that if one genuinely seeks to understand the beliefs or values of an alien culture, one is likely to find them worthy of consideration from a common point of view of humanity. The following statement by Nida sums up the essence of our study:

\begin{abstract}
Because translation always involves communication within the context of interpersonal relations, the model for such activity must be a communication model, and the principles must be primarily sociolinguistic in the broad sense of the term. As such, translating becomes a part of the even broader field of anthropological semiotics. (1976: 78)
\end{abstract}

The concept of translation as a metaphor for postcolonial writing broadens the horizon of the study of translation theory and practice to include other fields of inquiry such as history, sociology, ethnography, and anthropological semiotics. Postcolonial theory has had a significant impact on translation studies and has forced a rethinking of some commonly held views in translation theory by pointing out, for instance, that translation does not always take place between two stable, concrete and well-defined entities, thus questioning the relevance of a relentless search for equivalence and fluency which has characterized mainstream translation theory for so long.

\section{Bibliography}

\section{Primary texts}

Achebe, Chinua (1964). Arrow of God. London: Heinemann

Okara, Gabriel (1964). The Voice. London: Heinemann.

\section{Secondary texts}

Anozie, Sunday (1981). Structural Models and African Poetics: Towards a Pragmatic Theory of Literature. London: Routledge.

Austin, John (1962). How to Do Things with Words. Cambridge, MA: Harvard University Press.

Bassnett, Susan \& Harish Trivedi (eds) (1999). Post-Colonial Translation: Theory and Practice. London: Routledge. 
Berman, Antoine (1995). Pour une critique des traductions: John Donne. Paris: Gallimard.

Blum-Kulka, Shoshana (1985). "The multifunctionality of discourse markers: the case of requests." Theoretical Linguistics 12, 213-229.

Blum-Kulka, Shoshana, House, Juliane \& Gabriele Kasper (eds) (1989). CrossCultural Pragmatics: Requests and Apologies. Norwood, NJ: Ablex.

Brislin, Richard W. (ed.) (1976). Translation: Applications and Research. New York: Gardner.

Brower, Reuben A. (ed.) (1959). On Translation. Cambridge, MA: Harvard University Press.

Brown, Penelope \& Stephen Levinson (1978). "Universals of language usage: politeness phenomena." E. Goody (ed.) (1978). Questions and Politeness. Cambridge, UK: CUP, 56-324.

Chinweizu, Jemi Onwuchekwa \& Madubuike Ihechukwu. (1980). Toward the Decolonization of African Literature: African Fiction and Poetry and their Critics. London: Routledge.

Chishimba, Maurice (1984). African Varieties of English: Text in Context. Ph.D. Dissertation. University of Illinois at Urbana-Champaign.

Cole, Peter \& Jerry L. Morgan (eds) (1975). Syntax and Semantics 3: Speech Acts. New York: Academic Press,

Croft, Kenneth (ed.) (1980). Readings on English as a Second Language: for Teachers and Teacher Trainees. $2^{\text {nd }}$ edition. Cambridge, MA: Winthrop, 399-418.

Goody, Esther (ed.) (1978). Questions and Politeness. Cambridge, UK: CUP.

Enahoro, Peter (1966). How to Be a Nigerian. Lagos: The Daily Times of Nigeria.

Ervin-Tripp, Susan (1976). "Is Sybil there? The structure of some American English directives." Language in Society 5(1), 25-66.

Gadamer, Hans-Georg (1976). Philosophical Hermeneutics. (tr. E. Linge). Berkeley: University of California Press.

Green, Georgia (1975). "Nonsense and reference; or the conversational use of proverbs." Chicago Linguistics Society 11, 226-240.

Grice, Herbert Paul (1975). "Logic and conversation.” P. Cole \& L. Morgan (eds) (1975). Syntax and Semantics 3: Speech Acts. New York: Academic Press, 41-59.

Gumperz, John (1978). "The conversational analysis of inter-ethnic communication.” E. Lamar-Ross (ed.) (1978). Interethnic Communication. Athens, GA: University of Georgia Press, 13-31.

Habermas, Jürgen (1979). Communication and the Evolution of Society. (tr. T. McCarthy). Boston: Beacon Press.

Habermas, Jürgen (1984). The Theory of Communicative Action. (tr. T. McCarthy). Boston: Beacon Press.

Hymes, Dell (1972). "On communicative competence." J. Pride \& J. Holmes (eds) (1972) Sociolinguistics. The Hague: Mouton, 269-293.

Jakobson, Roman (1959). "On linguistic aspects of translation.” R.A. Brower (ed.) (1959). On Translation. Cambridge, MA: Harvard University Press, 232-239.

Kachru, Braj (1983). The Indianness of English: The English Language in India. London: Oxford University Press.

Kaplan, Robert (1980). "Cultural thought patterns in international education.” K. Croft (ed.) (1980). Readings on English as a Second Language: for Teachers and Teacher Trainees. $2^{\text {nd }}$ edition. Cambridge, MA: Winthrop, 399-418.

Lamar Ross, E. (ed.) (1978). Interethnic Communication. Athens, GA: University of Georgia Press. 
Lecercle, Jean-Jacques (1990). The Violence of Language. London/New York: Routledge.

Leech, Geoffrey (1983). Principles of Pragmatics. London: Longman.

McCarthy, Thomas (1978). The Critical Theory of Jürgen Habermas. Cambridge, MA: MIT Press.

Mehrez, Samia (1992). "Translation and the postcolonial experience: The Francophone North African text." L. Venuti (ed.) (1992). Rethinking Translation: Discourse, Subjectivity, Ideology. London: Routledge, 120-38.

Nida, Eugene (1976). "A framework for the analysis and evaluation of theories of translation." R.W. Brislin (ed.) (1976). Translation: Applications and Research. New York: Gardner, 47-91.

Obiechina, Emmanuel (1975). Culture, Tradition and Society in the West African Novel. Cambridge, UK: CUP.

Pride, John. \& Janet Holmes (eds) (1972). Sociolinguistics. The Hague: Mouton, 269-293.

Quine, Willard Van Orman (1960). Word and Object. Cambridge, MA: MIT Press.

Searle, John (1969). Speech Acts. Cambridge, UK: CUP.

Searle, John (1975). "Indirect speech acts.” P. Cole \& L. Morgan (eds) (1975). Syntax and Semantics 3: Speech Acts. New York: Academic Press, 59-82.

Snell-Hornby, Mary (1988). Translation Studies: An Integrated Approach. Amsterdam/Philadelphia: John Benjamins.

Tymoczko, Maria (1999). "Post-colonial writing and literary translation." S. Bassnett \& H. Trivedi (eds) (1999). Post-Colonial Translation: Theory and Practice. London: Routledge, 19-40.

Venuti, Lawrence (ed.) (1992). Rethinking Translation: Discourse, Subjectivity, Ideology. London: Routledge.

Wierzbicka, Anna (1985). "Different cultures, different languages, different speech acts." Journal of Pragmatics 9, 145-178.

Zabus, Chantal (1991). The African Palimpsest: Indigenization of language in the West African Europhone novel. Amsterdam: Rodopi. 